\title{
DETERMINAN KEPUTUSAN PEMBELIAN PRODUK GREEN LABEL BERDASARKAN GREEN PRODUCT DAN GETOK TULAR
}

\author{
Metta Padmalia \\ Jurusan Manajemen, Fakultas Manajemen \& Bisnis, Universitas Ciputra, Surabaya \\ Email: metta.padmalia@ciputra.ac.id \\ Submitted: May 12, 2017; Reviewed: May 17, 2017; Accepted: Aug 20, 2017
}

\begin{abstract}
The study was conducted to identify the characteristics of consumers for products with a green label, analyzing the influence of aspects of green product and word of mouth to the label green product purchasing decisions. The sampling method using a convenience sampling, involving 100 respondents who are students in Surabaya with a minimum age of 17 years and they've bought green labels products. Data were analyzed using the Partial Least Squares (PLS). The results of PLS analysis shows that there is impact of green input, green output, and word of mouth to purchasing decision with coefficient value 0.2444, 0.2461, 0.4664 for each, while green process doesn't have impact to purchase decision. These results indicate that consumers consider important aspects of green input and green output that can be felt directly, while green process can't be felt immediately. Moreover, in deciding to buy a product green label, recommendations from others considered important by consumers.
\end{abstract}

Keywords: Green Label, Green Product, Word of Mouth, Purchasing Decision

\section{PENDAHULUAN}

Aktivitas manusia di berbagai bidang ilmu pengetahuan dan teknologi, pertanian, serta ekonomi dan bisnis baik secara langsung maupun tidak langsung berdampak pada permasalahanpermasalahan lingkungan hidup. Fenomena tersebut telah menjadi issue sentral bagi semua lapisan masyarakat. Kepedulian dan kesadaran akan permasalahan lingkungan telah merubah cara pandang dan pola hidup manusia, termasuk para pebisnis dan pengusaha. Hal tersebut dapat dilihat pada perubahan pola pendekatan bisnis yang mulai mengarah ke pendekatan aktivitas bisnis berbasis kelestarian lingkungan. Selain itu, banyak pula perusahaan telah menerapkan program CSR (Corporate Social Responsibility) sebagai bentuk kepedulian sosial dan lingkungan. Green consumerism menurut Moisander dan Pesonen (2002) muncul sebagai gerakan konsumerisasi global dengan mulai munculnya kesadaran para konsumen akan hak-haknya untuk mendapatkan produk-produk yang aman dan dapat mengurangi tingkat kerusakan lingkungan. Green consumerism adalah perilaku konsumen yang timbul karena keinginan untuk memenuhi kebutuhannya, selain itu juga karena kepedulian terhadap kesejahteraan lingkungan dan sosial secara keseluruhan (Moisander \& Pesonen, 2002).

Adanya peningkatan kesadaran terhadap isu lingkungan hidup mendorong dunia industri menciptakan konsep pemasaran yang mengutamakan isu lingkungan, konsep ini dikenal sebagai green marketing (Syahbandi, 2012). Syahbandi (2012) berpendapat bahwa green marketing muncul sebagai konsep pemasaran baru yang berkembang dan diakui eksistensinya oleh para konsumen berbagai produk yang ditawarkan perusahaan. Fenomena tersebut sejatinya membuka peluang bisnis dalam upaya mengembangkan dan mengimplementasikan rencana jangka panjang secara proaktif pada strategi kepedulian lingkungan oleh perusahaan (Kalafatis et al., 1999). Pendekatan green marketing merupakan pendekatan dalam pemasaran strategik yang 
menarik perhatian banyak perusahaan dan industri sejak abad ke-20 (Byrne, 2003).

Green marketing merupakan salah satu hal yang bisa memengaruhi perasaan emosi serta perencanaan konsumen, sehingga dapat berdampak terhadap minat beli. Produk-produk yang berlabel go green bermunculan dengan tujuan untuk menyampaikan bahwa ketika produk-produk tersebut dikonsumsi maka akan ada nilai lebih. Oleh karena itu, selain mereka memperoleh benefit dari produk, mereka juga dianggap telah menjaga kelestarian lingkungan. American Marketing Association (AMA) dalam Agustin et al. (2015) mendefinisikan "green marketing sebagai proses pemasaran produk yang diasumsikan aman bagi lingkungan". Kesadaran terhadap permasalahan lingkungan memicu dunia industri mengembangkan konsep pemasaran yang berfokus pada isu lingkungan melalui green marketing. Menurut pengamat pemasaran, green marketing lahir sebagai gaya hidup yang semakin berkembang dan diakui keberadaannya. Berbagai produk ditawarkan oleh industri yang mengedepankan green marketing melalui atribut-atribut yang mencakup green input, green process, dan green output.

Aktivitas pemasaran melalui green marketing berorientasi kepada pelestarian lingkungan, dengan menilai sejauh mana perusahaan dan pemasar mencari cara memproduksi dan memasarkan barang serta jasa yang ramah lingkungan. Setiyaningrum et al. (2015) menyebutkan bahwa eco label, eco brand, dan iklan bertema lingkungan merupakan alatalat green marketing yang dapat meningkatkan pengetahuan konsumen mengenai produk ramah lingkungan. Alat-alat green marketing tersebut menjadi sarana yang memudahkan konsumen mempersepsikan green product, memunculkan kesadaran akan green product, dan mendorong konsumen membeli produk ramah lingkungan.

Menurut Hakim (2010), green marketing tidak hanya melakukan pemasaran berorientasi lingkungan pada aktivitas promosi dan desain produk dengan karakteristik yang sesuai dengan kelestarian lingkungan, tetapi juga pada proses dan teknik produksinya. Isu lingkungan hidup bukan saja untuk membangun citra (image) baik, bahkan bisa dijadikan dasar positioning yang kuat bagi perusahaan, terlebih apabila isu lingkungan telah menjadi kebutuhan bagi konsumen. Oleh karena itu, green product terdiri atas aspek-aspek: green input, green process, dan green output yang menjadi pertimbangan konsumen dalam memutuskan membeli produk 92 berlabel hijau.

Menurut Jamrozy (2007), pendekatan pemasaran yang berkelanjutan lebih berfokus pada pemasaran alternatif dan berdasarkan ide bahwa perusahaan seharusnya mengintegrasikan tujuan ekonomi, sosial kemasyarakatan, dan tujuan lingkungan dalam menjalankan bisnis. Setiyaningrum et al (2015) menambahkan bahwa banyak green product mengalami perkembangan pesat dan memperoleh kepercayaan dari konsumen, seiring dengan penerapan teknologi yang makin canggih, penguatan pernyataan yang lebih tegas pada klaim iklan, regulasi dan insentif pemerintah, serta pemeriksaan lebih dekat dari berbagai organisasi lingkungan dan media. Oleh karena pesatnya perkembangan tren green product maka perusahaan perlu memperhatikan aspek-aspek yang memengaruhi keputusan pembelian produk dengan label hijau supaya dapat bertahan dalam persaingan pasar.

Menurut pengamatan Aruman pada tahun 2007, terdapat peningkatan dalam nilai getok tular (word of mouth) pada dunia promosi penjualan dari tahun ke tahun hingga pada tahun 2007 menjadi $92 \%$. Konsumen sebagian besar lebih mempercayai pengalaman orang yang sebelumnya telah menggunakan produk tertentu dan mengomunikasikan hal-hal yang berkaitan dengan produk yang akan dibeli tersebut. Komunikasi getok tular dapat tersebarluas lewat jaringan bisnis, masyarakat, dan sosial yang dianggap berpengaruh terhadap masyarakat di suatu lokasi tertentu (Hasan, 2010). Pendekatan promosi getok tular dalam menawarkan suatu produk untuk menimbulkan minat pembelian sesuai dengan teori yang dikemukakan oleh Destari dan Kasih (2014) membuktikan bahwa getok tular memengaruhi keputusan pembelian.

Penelitian terdahulu Harrison-Walker (2001) menunjukkan bahwa setiap seorang konsumen yang puas akan memberitahukan kepada 3-5 orang lain tentang pengalamannya, sedangkan yang tidak puas akan memberitahukan kepada 10-11 orang. Hal ini memperlihatkan bahwa konsumen lebih sering menceritakan ketidakpuasan terhadap produk ketimbang kepuasannya. Oleh karena itu, maka perusahaan perlu memperhatikan getok tular negatif tentang perusahaannya yang pada akhirnya akan memengaruhi keputusan pembelian produk (Kartajaya \& Ridwansyah, 2012). Walaupun perusahaan gencar melakukan promosi melalui iklan-iklan yang banyak dan menarik, tetapi jika ada pengalaman yang buruk mengenai perusahaan tersebut, maka akan 
menyebar sangat cepat. Pihak perusahaan hendaknya mengarahkan terjadinya getok tular yang positif dari para pelanggannya supaya dapat lebih meningkatkan keputusan pembelian konsumen terhadap produknya. Oleh karena itu, aspek-aspek yang membentuk pemahaman tentang green product dan adanya getok tular positif yang dapat memengaruhi keputusan pembelian konsumen penting untuk diteliti lebih lanjut.

Berdasarkan situasi problematik yang telah dijabarkan, maka tujuan penelitian ini adalah: (1) Mengetahui pengaruh green input terhadap keputusan pembelian produk dengan green label; (2) Mengetahui pengaruh green process terhadap keputusan pembelian produk dengan green label; (3) Mengetahui pengaruh green output terhadap keputusan pembelian produk dengan green label; dan (4) Mengetahui pengaruh getok tular terhadap keputusan pembelian produk green label.

Adapun manfaat dari penelitian ini secara teoretis adalah dapat digunakan sebagai kajian ilmiah di bidang pemasaran khususnya getok tular dan keputusan pembelian produk green label. Penelitian ini secara praktis juga diharapkan dapat digunakan sebagai masukan dan pertimbangan perusahaan supaya memperhatikan aspek-aspek green product yang terdiri atas bahan baku pembuatan produk, proses produksi, serta output yang dihasilkan dari proses produksi sehingga dapat lebih mendorong konsumen melakukan pembelian produknya. Selain itu, hasil penelitian ini diharapkan dapat mendukung penelitian yang mengintegrasikan aspek lingkungan dengan pemasaran untuk mendukung tren produk dengan green label.

\section{LANDASAN TERORI, KAJIAN EMPIRIS \& PENGEMBANGAN HIPOTESIS}

\section{Proses Pengambilan Keputusan}

Menurut Sumarwan (2011), keputusan didefinisikan sebagai pemilihan suatu tindakan dari dua atau lebih alternatif. Apabila konsumen tidak memiliki pilihan sebagai alternatif, kondisi tersebut bukanlah suatu situasi konsumen melakukan keputusan. Keputusan pembelian menurut Peter dan Olson (2006) adalah "proses mengkombinasikan pengetahuan untuk mengevaluasi dua atau lebih perilaku alternatif dan memilih salah satu di antaranya". Keputusan pembelian terbentuk melalui pemahaman konsumen tentang keinginan dan kebutuhan terhadap suatu produk tertentu dengan menilai dari sumber yang ada, kemudian menetapkan tujuan pembelian, serta mengidentifikasi alternatif, hingga mengambil keputusan untuk membeli disertai dengan perilaku pasca-beli (Swastha \& Irawan, 2008). Secara umum menurut Kotler dan Armstrong (2012), keputusan pembelian berupa tahap penilaian keputusan yang menyebabkan pembeli membentuk pilihan di antara beberapa merek yang tergabung dalam perangkat pilihan dan membentuk tujuan membeli. Setiadi (2003) menjelaskan tentang proses keputusan pembelian dalam lima tahapan, dengan masing-masing indikator yang dapat memengaruhi tindakan konsumen (Gambar 1).

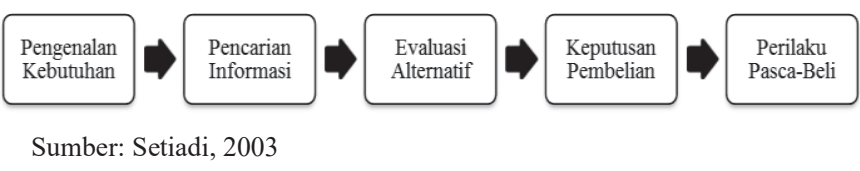

Gambar 1. Tahapan Proses Keputusan Pembelian

Menurut Setiadi (2003), tahap pertama proses keputusan pembelian berupa pengenalan masalah, suatu keadaan di mana terdapat perbedaan antara keadaan yang diinginkan dengan keadaan yang terjadi sebenarnya. Tahap kedua adalah pencarian informasi untuk mengumpulkan alternatif dari berbagai sumber (Setiadi, 2003). Tahap ketiga berupa evaluasi alternatif untuk mengevaluasi pilihan produk atau merek dan memilihnya sesuai dengan yang diinginkan konsumen (Setiadi, 2003). Tahap keempat yaitu pengambilan keputusan pembelian konsumen yang dapat diukur melalui seberapa besar pengaruh dari orang lain, kenginan dan kemampuan konsumen serta intensitas pembelian konsumen (Setiadi, 2003). Tahap terakhir adalah perilaku pasca pembelian ketika konsumen mengevaluasi produk yang dibelinya apakah memuaskan atau tidak (Setiadi, 2003); apabila memuaskan dan sesuai dengan harapan konsumen maka ada kemungkinan ia akan kembali membeli produk yang dijual perusahaan.

Setiadi (2003) lebih lanjut menjelaskan bahwa keputusan pembelian dapat dijelaskan dari aspek-aspek berikut: produk dapat memenuhi kebutuhan konsumen, penelusuran informasi dari orang lain, perbandingan merek sebelum memutuskan pembelian, pertimbangan yang matang sebelum terjadi keputusan pembelian, serta puas atau tidaknya konsumen 
terhadap keputusan beli yang diambil.

\section{Green Product}

Produk adalah segala sesuatu yang dapat ditawarkan ke pasar untuk mendapatkan perhatian, dibeli, digunakan, atau dikonsumsi yang dapat memuaskan keinginan atau kebutuhan konsumen (Kotler \& Armstrong, 2012). Green product dapat didefinisikan sebagai suatu produk yang ramah atau tidak berbahaya terhadap lingkungan, baik ketika proses produksi maupun saat proses konsumsinya. D'Souza et al. (2006) menjelaskan bahwa green product adalah produk yang memiliki manfaat bagi konsumen dan juga memiliki manfaat sosial yang dirasakan oleh konsumen, seperti ramah terhadap lingkungan.

Green product seringkali dianggap sebagai produk ramah lingkungan yang menurut Handayani (2012), merupakan produk yang dirancang dan diproses dengan cara-cara tertentu untuk mengurangi efek pencemaran lingkungan, baik dalam sistem produksi, distribusi, maupun konsumsinya. Kriteria produk ramah lingkungan menurut D'Souza et al (2006) meliputi hal-hal berikut: (1) persepsi produk, konsumen melihat green product atau produk ramah lingkungan sebagai produk yang tidak berbahaya terhadap hewan dan lingkungan; (2) kemasan produk, menyajikan elemen tertentu dan terlihat terkait kepedulian lingkungan oleh pelanggan; serta (3) komposisi isi, ditunjukkan dengan kandungan bahan daur ulang pada pemakaian batas tertentu dan kerusakan yang minim terhadap lingkungan.

Hasil penelitian Hakim (2010) menunjukkan bahwa terdapat tiga aspek green product sebagai berikut. Pertama, green input yang merupakan sejumlah material ramah lingkungan yang dijadikan sebagai sumber bahan baku dari sebuah produk. Green input terdiri dari komposisi produk, karakteristik bahan baku, keberadaan bahan pengawet, dan bahan baku pertanian organik. Kedua, green process yang merupakan tahapan produksi yang memperhatikan dampak terhadap lingkungan. Atribut ini terdiri dari penggunaan energi efisien, limbah proses produksi, pengurangan emisi, dan tidak melakukan uji produk terhadap binatang (no animal testing). Ketiga, green output dengan kriteria produk dengan dampak minimal terhadap lingkungan. Green output terdiri dari penggunaan kemasan yang dapat diurai secara alami (biodegradable), eco label, ketahanan produk, dan sertifikasi produk (Hakim, 2010).

Indonesia Green Product mengungkapkan bahwa untuk mengidentifikasi green product setidaknya ada dua cara yang bisa dilakukan. Pertama adalah dengan melihat label yang berupa logo atau pernyataan pada produk atau kemasan yang mengidentifikasin produk hijau. Label tersebut biasanya disebut dengan eco label. Label lingkungan atau ekolabel tersebut diartikan sebagai pernyataan yang menunjukan aspek lingkungan dalam suatu produk atau jasa (ISO 14020 : 1998 (E)) (Utomo, 2015). Sehingga produk dengan ekolabel dapat menjadi indikator bahwa produk tersebut ramah lingkungan dibanding produk sejenis yang tidak berekolabel. Cara kedua mengidentifikasi green product adalah dengan melihat pernyataan pada produk atau kemasan yang berupa informasi mengenai komposisi produk, cara penggunaan atau penanganan ketika sudah tidak digunakan lagi. Jadi, produk dengan green label berdasarkan uraian Utomo (2015) dapat diartikan sebagai produk yang memiliki eco label sebagai bukti bahwa produk tersebut ramah terhadap lingkungan.

\section{Getok Tular}

Word of Mouth Marketing Association mendefinisikan getok tular sebagai usaha untuk meneruskan informasi dari satu konsumen ke konsumen lain (Sumardy et al., 2011). Proses getok tular tidak dapat dibuat-buat karena dilakukan oleh konsumen dengan sukarela tanpa mendapatkan imbalan (Wirtz \& Chew, 2002). Tipe komunikasi personal tersebut dipandang sebagai sumber yang lebih dapat dipercaya atau dapat diandalkan ketimbang dengan informasi dari non-personal. Komunikasi ini menurut Sumardy et al (2011) juga dipandang sebagai jenis aktivitas pemasaran paling efektif di Indonesia.

Ketika pelanggan menyebarkanluaskan pendapatnya tentang keunggulan dan kebaikan produk, kondisi tersebut adalah getok tular positif. Namun, ketika pelanggan menyebarluaskan pendapat mengenai keburukan produk, maka disebut sebagai getok tular negatif. Getok tular positif sangat penting ketika seseorang melakukan bisnis dengan suatu perusahaan dan memberi rekomendasi kepada orang lain mengenai perusahaan dan produk yang dijual. Penelitian sebelumnya menyatakan bahwa getok tular positif sembilan kali lebih efektif dibandingkan periklanan (Babin, Lee, Kim, \& Griffin, 2005). Pada awalnya, komunikasi getok tular dipandang sebelah mata karena sifatnya "one to one" terbatas hanya pada 
suatu area tertentu saja (Sumardy et al., 2011). Akan tetapi, saat ini jumlah media massa sudah membludak dan teknologi komunikasi berkembang pesat, sehingga menciptakan komunikasi "one to many". Komunikasi getok tular semakin diminati para pelaku bisnis karena mudah menyebar melalui media. Masyarakat juga lebih percaya pada cerita pengalaman orang lain yang telah menjadi pengguna produk atau jasa sebelumnya, ketimbang janji-janji perusahaan (Solomon, 2011).

Semakin banyaknya pilihan media dan kemajuan teknologi internet menyebabkan konsumen dengan mudah dapat mencari informasi mengenai suatu produk. Konsumen juga dapat mengungkapkan rasa suka atau tidak sukanya terhadap suatu produk baik melalui komunitas tradisional maupun komunitas di dunia maya seperti Instagram, Facebook, Twitter, dan sebagainya. Getok tular memanfaatkan jejaring sosial yang diakses melalui internet yang dikenal pula sebagai word of mouse (Sumardy et al., 2011; Thalauw, 2013). Solomon (2011) menambahkan bahwa sejak tahun 2000 internet memasuki fase Web 2.0 yang lebih interaktif. Perkembangan tersebut secara tidak langsung mengarahkan model komunikasi getok-tular menjadi komunikasi "many to many" melalui jejaring sosial yang diikuti masyarakat dengan mudah (Sumardy et al., 2011).

Indikator yang digunakan dalam penelitian ini untuk menjelaskan tentang getok tular sesuai dengan Assael (1998), yaitu: (1) Product News, ketika konsumen merekomendasikan tentang keistimewaan produk kepada orang lain; (2) Personal experience, bahwa konsumen memperoleh informasi produk dari orang lain yang dia percaya; serta (3) Advice giving, ketika konsumen dianjurkan untuk membeli suatu produk tertentu dari orang lain yang dia percaya.

\section{Pengembangan Hipotesis}

Green consumer merupakan tipe konsumen yang dewasa ini gencar memburu produk-produk ramah lingkungan (green product) demi memenuhi kebutuhannya (Moisander \& Pesonen, 2002). Kebutuhan green consumer dalam memenuhi kebutuhan green product, mengindikasikan adanya keterhubungan antara green product dan keputusan pembelian konsumen. Oleh karena itu, diduga bahwa aspekaspek dari green product berpengaruh terhadap keputusan pembelian produk dengan green label.

Hakim (2010) mengungkapkan bahwa green input menunjukkan bagaimana perusahaan menggunakan sejumlah material ramah lingkungan sebagai sumber bahan baku dalam memproduksi produknya. Lebih lanjut, menurut Hakim (2010) dan Manongko (2011) bahan baku ramah lingkungan yang digunakan merupakan pertimbangan pertama yang dapat memengaruhi keputusan pembelian green product, sehingga hipotesis pertama dalam penelitian ini:

$\mathrm{H}_{1}$ : green input memengaruhi keputusan pembelian produk dengan green label.

Aspek lainnya yang mengindikasi suatu green product dapat dilihat dari proses produksi yang dilakukan. Hakim (2010) menyebutkan bahwa green product diklaim melakukan tahapan-tahapan produksi yang ramah lingkungan. Proses produksi yang antara lain terdiri dari penggunaan energi efisien, penanganan limbah proses produksi, pengurangan emisi, dan no animal testing dapat memengaruhi keputusan konsumen dalam pembelian green product. Oleh karena itu, hipotesis kedua dalam penelitian ini:

$\mathrm{H}_{2}$ : green process memengaruhi keputusan pembelian produk dengan green label.

Aspek terakhir yang menurut penelitian Hakim (2010) dan Manongko (2011) mendukung suatu produk sebagai green product adalah output dari produk yang tidak berdampak buruk bagi lingkungan, misalnya dengan penggunaan kemasan yang dapat diurai secara alami dan sertifikasi produk yang ramah lingkungan. Seseorang memutuskan untuk membeli green product berharap agar sampah yang diakibatkan dari konsumsi produk tersebut tidaklah berbahaya bagi lingkungan, sehingga hipotesis ketiga dalam penelitian ini:

$\mathrm{H}_{3}$ : green output memengaruhi keputusan pembelian produk dengan green label.

Hal yang patut dipertimbangkan pula adalah tingginya arus informasi dan teknologi saat ini. Tingginya arus informasi dan teknologi tersebut menjadikan konsumen dapat memahami berbagai informasi dengan lebih mudah, kekuatan ini mendorong komunikasi getok tular menjadi salah satu bagian dari pemasaran yang sangat penting. Getok tular positif pada sebuah produk dapat menjadi upaya yang direncanakan dan dikomunikasikan sehingga memengaruhi keputusan pembelian terhadap produk (Destari dan Kasih, 2014).

$\mathrm{H}_{4}$ : getok tular memengaruhi keputusan pembelian produk dengan green label.

\section{METODE PENELITIAN}

Penelitian ini dikembangkan melalui 
pendekatan kuantitatif dengan metode survei yang bertujuan untuk menjelaskan fenomena empiris disertai data statistik, karakteristik responden, dan pola keterhubungan antarvariabel. Metode survei dipilih sebagai sumber data primer melalui penyebaran kuesioner. Pengumpulan data pada penelitian survei dilakukan dengan menggunakan instrumen atau wawancara untuk mendapatkan tanggapan dari responden (Sugiyono, 2009). Data sekunder diperoleh melalui bahan literatur yang terkait dengan rancangan penelitian. Penelitian ini termasuk penelitian asosiatif, yang mencari hubungan atau pengaruh variabel bebas green input, green process, green output, dan getok tular terhadap variabel terikat keputusan pembelian.

Pengambilan sampel mengunakan metode non probability sampling melalui convenience sampling. Sampling berdasarkan pertimbangan tertentu yaitu dengan syarat responden berdomisili di Kota Surabaya, dengan rentang usia mahasiswa Strata-1 (17-25 tahun), dan sudah pernah membeli produk green label. Alasan pemilihan responden di usia mahasiswa didasarkan pada temuan Roberts dan Bacon (1997), di mana profil demografis usia tersebut berhubungan erat dengan konsumen green product yang belum mencapai middle-age atau masih berusia muda.

Metode untuk menentukan jumlah sampel berdasarkan Hair (1995) yang menyatakan bahwa ukuran sampel yang sesuai adalah antara 100 sampai 200, dengan ukuran sampel minimum adalah sebanyak 5 observasi untuk setiap estimated parameter dan maksimal adalah 10 observasi dari setiap estimated parameter. Dalam penelitian ini, jumlah pertanyaan kuesioner adalah sebanyak 20 item, oleh karena itu jumlah sampel yang diperlukan sebanyak 5 kali jumlah pertanyaan atau sebanyak 100 orang.

Instrumen dalam penelitian ini berupa kuesioner yang berisi butir-butir pertanyaan untuk diberi tanggapan oleh responden. Penyusunan kuesioner didasarkan pada konstruksi teoretis yang telah disusun sebelumnya. Kemudian atas dasar teoretis tersebut dikembangkan dalam indikator-indikator dan selanjutnya dikembangkan ke dalam butirbutir pertanyaan. Instrumen disusun menggunakan skala likert. Adapun operasionalisasi variabel dalam penelitian ini adalah sebagai berikut (Tabel 1).
Tabel 1. Operasionalisasi Variabel

\begin{tabular}{|c|c|c|}
\hline $\begin{array}{c}\text { Jenis } \\
\text { Variabel }\end{array}$ & Definisi Operasional & Indikator \\
\hline $\begin{array}{l}\text { Green Input } \\
\text { (X1) }\end{array}$ & $\begin{array}{l}\text { Green input merupakan penggunaan sejumlah } \\
\text { material ramah linghangan sebagai sumber } \\
\text { bahan baku dari produlk dengan green label } \\
\text { (Hakim, 2010). }\end{array}$ & 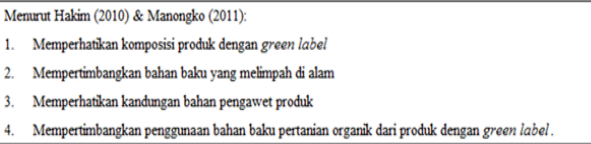 \\
\hline $\begin{array}{c}\text { Green } \\
\text { Process }(\mathrm{X} 2)\end{array}$ & $\begin{array}{l}\text { Green process merupakan tahapan produksi } \\
\text { yang memperhathkan dampak terhadap } \\
\text { linghungan (Hakim, 2010). }\end{array}$ & 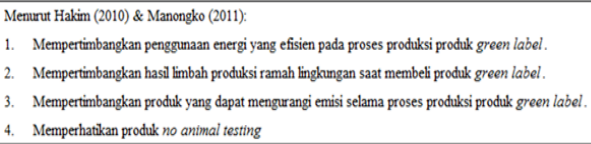 \\
\hline $\begin{array}{l}\text { Green Output } \\
\text { (X3) }\end{array}$ & $\begin{array}{l}\text { Green output merupakan aspek dari green } \\
\text { product dengan dampak minimal terhadap } \\
\text { lingkangan (Hakim, 2010). }\end{array}$ & $\begin{array}{l}\text { Menurut Hakim }(2010) \text { \& Manongko ( } 2011) \text { : } \\
\text { 1. Memperhatikan penggunaan kemasan biodegradable (kemasan dari bahan yang mudah duraikan). } \\
\text { 2. Mempertimbangkan keberadaan eco label. } \\
\text { 3. Mempertimbangkan produk yang tahan lama. } \\
\text { 4. Mempertimbangekan sertifikat ramah linghangan pada produk. }\end{array}$ \\
\hline $\begin{array}{l}\text { Getok Tular } \\
(\mathrm{X} 4)\end{array}$ & $\begin{array}{l}\text { Getok tular adalah usaha pemasaran yang } \\
\text { mendorong konsumen membicarakan, } \\
\text { mempromosikan, dan merekomendaskikan } \\
\text { produk merek perushahan kepada orang lain } \\
\text { (Hajjadi dan Fatmasari, 2008) }\end{array}$ & $\begin{array}{l}\text { Menurut Assael (1998): } \\
\text { 1. Product News: merekomendaskikan tentang keistimewaan produkk kepada keluarga dan rekan saya. } \\
\text { 2. Personal experience : mendapatkan informasi produlk dari ketharga atau teman saya. } \\
\text { 3. Adivice giving: dianjurkan untuk membel produk green label dari keluarga atau teman saya. }\end{array}$ \\
\hline $\begin{array}{l}\text { Kepuntusan } \\
\text { Pembelian (Y) }\end{array}$ & $\begin{array}{l}\text { Keputusan pembelian adalah proses } \\
\text { mengkombinaskikan pengetahuan unnuk } \\
\text { mengevahuasi dua atau lebhi alternatif dan } \\
\text { memilh salah satu di antaranya (Peter dan } \\
\text { Olson, 2006) }\end{array}$ & 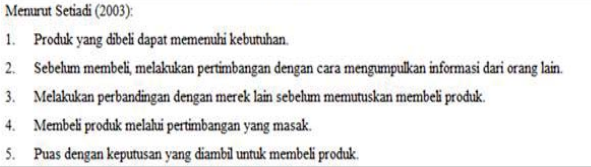 \\
\hline
\end{tabular}

Data penelitian kemudian dianalisis melalui Structural Equation Modeling (SEM) yang berbasis component atau variance atau disebut Partial Least Squares (PLS). Alat statistika yang digunakan dalam penelitian ini adalah SmartPLS 3.

\section{HASIL DAN PEMBAHASAN}

Analisis deskriptif bertujuan untuk mengetahui karakteristik responden secara umum. Karakteristik responden dilihat dari usia, gender, uang saku/ pendapatan tiap bulan, produk dengan green label yang biasanya dikonsumsi, dan frekuensi membeli produk green label dalam sebulan dapat dilihat pada Tabel 2.

Tabel 2. Karakteristik Responden (Total Responden $=100)$

\begin{tabular}{llc}
\hline \multicolumn{1}{c}{ Kategori } & \multicolumn{1}{c}{ Alternatif Jawaban } & Jumlah (orang) \\
\hline Gender & Laki-laki & 38 \\
& Perempuan & 62 \\
\hline Usia & $17-19$ tahun & 40 \\
& $20-22$ tahun & 54 \\
& $23-25$ tahun & 6 \\
\hline & Di bawah Rp 1.000.000,- & 29 \\
& Rp 1.000.000,-s/d Rp 2.000.000,- & 23 \\
& Rp 2.000.000,-s/d Rp 3.000.000,- & 19 \\
Uang Saku/ Pendapatan per bulan & Rp 3.000.000,-s/d Rp 4.000.000,- & 10 \\
& Rp 4.000.000,-s/d Rp 5.000.000,- & 13 \\
& Di atas Rp 5.000.000,-- & 6 \\
\hline Produk dengan green label yang & Kosmetik dan Skin-care & 30 \\
biasanya dibeli (responden dapat & Toiletries & 51 \\
memilih lebih dari satu pilihan) & Makanan dan Minuman & 55 \\
& Lainnya & 1 \\
\hline \multirow{2}{*}{ Frekuensi pembelian dalam } & Jarang & 21 \\
sebulan & Kadang-kadang & 53 \\
& Sering & 26 \\
\hline Sumber: Data
\end{tabular}

Sumber: Data diolah (2017) 
Berdasarkan Tabel II tampak bahwa mayoritas responden yang membeli produk dengan green label adalah perempuan (62\%). Konsumen perempuan menurut penelitian Miranti pada tahun 2012 menunjukkan nilai yang lebih besar daripada konsumen laki-laki pada sikap dan kepedulian terhadap lingkungan, persepsi terhadap keseriusan masalah lingkungan, dan persepsi mengenai tanggung jawab kepada lingkungan pada perilaku pembelian produk ramah lingkungan. Berdasarkan demografi usia mayoritas responden berusia 20-22 tahun (54\%).

Jika dilihat dari pendapatan, responden yang menjadi konsumen produk green label mayoritas memiliki pendapatan di bawah $\mathrm{Rp}$ 1.000.000,00; sehingga walau tidak berpendapatan tinggi, konsumen memilih produk hijau karena harga masih terjangkau. Hal itu didukung hasil wawancara singkat pada beberapa konsumen bahwa mereka memilih produk green label karena harga tidak berbeda jauh tetapi kualitas yang mereka persepsikan lebih baik daripada yang lain. Mayoritas produk yang dibeli oleh responden adalah makanan dan minuman (55 orang). Frekuensi pembelian produk green label dalam sebulan mayoritas ada di kriteria "kadang-kadang" sebanyak 53\%.

Variabel laten dalam penelitian ini terdiri dari lima variabel, dengan tiap variabel laten masing-masing memiliki indikator reflektif. Metode analisis dilakukan untuk mengetahui pengaruh variabel laten eksogen (green input, green process, green output, dan getok tular) terhadap variabel laten endogen (keputusan pembelian produk green label). Diagram path awal dari hasil uji algoritma dapat dilihat pada Gambar 2.

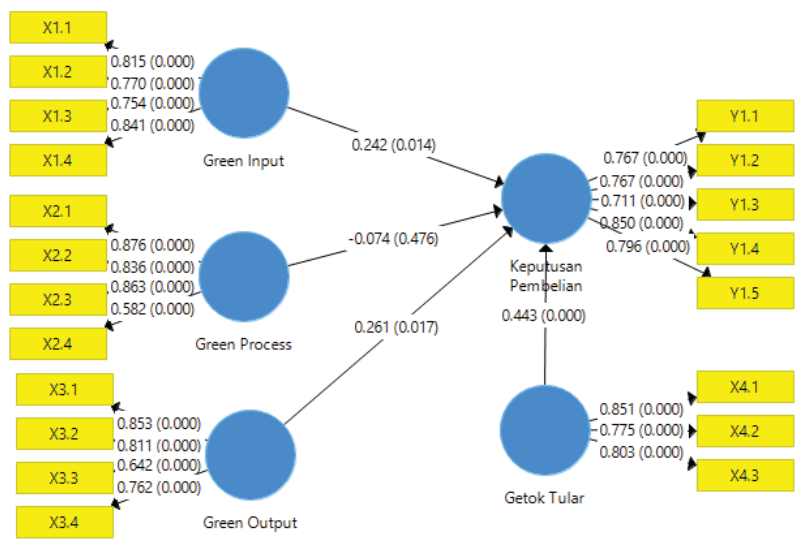

Gambar 2. Diagram path awal dari hasil uji algoritma
Indikator reflektif dianggap reliable apabila memiliki nilai korelasi di atas 0,70. Berdasarkan pada nilai loading factor diagram path (Gambar 2), maka indikator X2.4 dan X3.3 dikeluarkan dari model karena loading factor kurang dari 0,70. Setelah itu dilakukan estimasi ulang dan hasilnya telah memenuhi convergent validity.

Pengujian model pada analisis SEM-PLS dilakukan melalui analisis evaluasi model pengukuran (Outer Model) dan evaluasi model struktural (Inner Model). Evaluasi outer model dianalisis dengan convergent validity, discriminant validity, dan composite reliability (Ghozali, 2008). Tahan pertama pengujian outer model yaitu melihat nilai Loading factor harus memiliki nilai di atas 0,70 untuk dinyatakan memiliki tingkat valid yang baik atau mampu mencerminkan variabel eksogen dan endogen. Seluruh loading factor pada indikator tiap variabel penelitian ini telah memiliki nilai di atas 0.70, sehingga telah memenuhi convergent validity (Gambar 3).

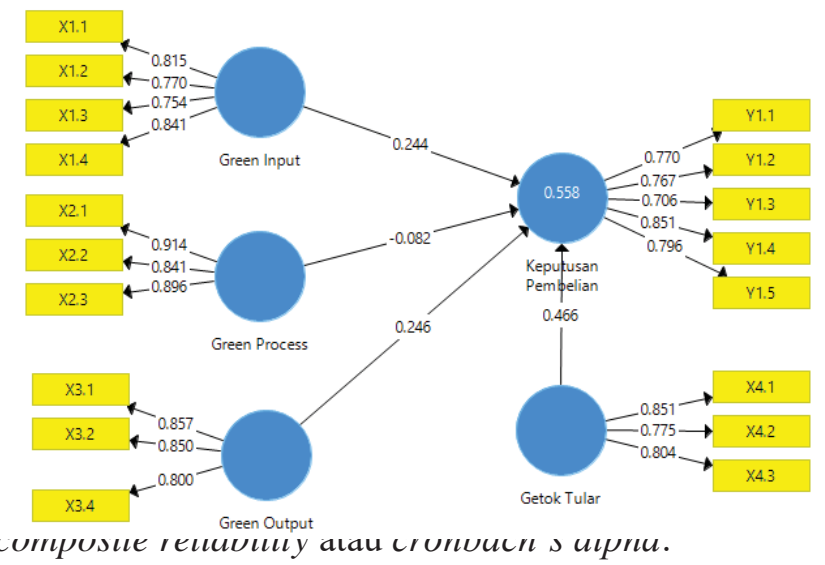

Gambar 3. Diagram path setelah dilakukan estimasi ulang

Kriteria suatu konstruk dapat dikatakan reliabel adalah ketika nilai composite reliability atau cronbach's alpha lebih dari 0,70. Dari hasil output SmartPLS, seluruh konstruk laten variabel endogen dan eksogen memiliki nilai composite reliability dan cronbach's alpha lebih dari 0,70 sehingga semua konstruk memiliki tingkat reliabilitas yang baik. Tahap evaluasi selanjutnya yaitu dengan melihat discriminant validity yang baik (nilai AVE lebih dari 0,50). Berdasarkan output SmartPLS, semua nilai AVE variabel laten memiliki nilai di atas 0,50 , menunjukkan bahwa semua konstruk memiliki tingkat validitas yang baik.

Pengujian berikutnya adalah evaluasi 
model struktural (Inner Model). Evaluasi model struktural mengambarkan keterhubungan antara variabel laten eksogen dengan endogen dilihat dari hasil output SmartPLS (Path Coefficient) dan nilai t-statistik dapat dilihat pada Tabel III. Hasil uji bootstraping dapat dilihat pada Gambar 4.

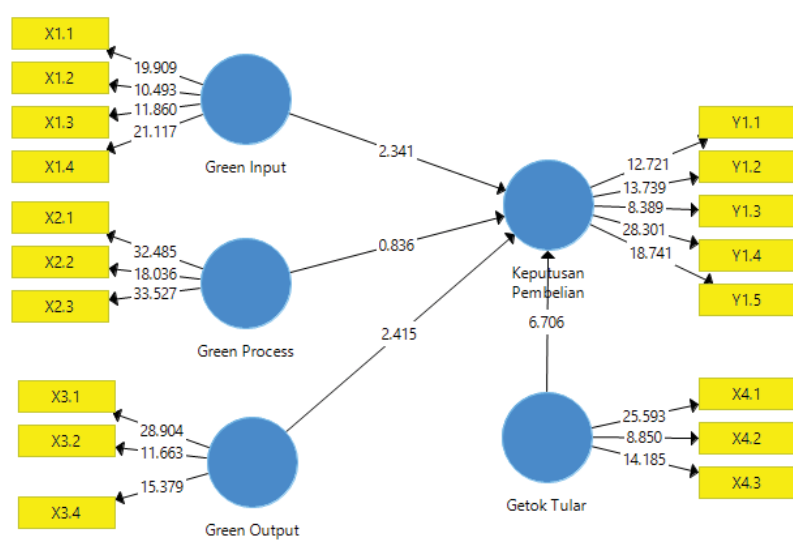

\section{Gambar 4. Hasil Uji Bootstraping (t-value/ statistics)}

Berdasarkan output SmartPLS, konstruk green input, green output, green process, dan getok tular mampu menjelaskan konstruk keputusan pembelian sebesar 0,5581 atau 55,81 $\%$; sedangkan sisanya $44,19 \%$ diterangkan oleh konstruk lainnya yang tidak dihipotesiskan dalam model penelitian ini.

Permasalahan penelitian dijawab melalui uji hipotesis. Pengujian hipotesis dilihat dari nilai t-statistics (Tabel III). Batas untuk menolak dan menerima hipotesis yang diajukan adalah $t$ statistics 1,960 .

Tabel 3. Hasil Pengujian Hipotesis

\begin{tabular}{|c|c|c|c|}
\hline & Original Sample $(\mathbf{O})$ & $t$-statistics & Kesimpulan \\
\hline Green Input $\rightarrow$ Keputusan Pembelian & 0,2444 & $2,3405^{*}$ & Terima $\mathrm{H}_{1}$ \\
\hline Green Process $\rightarrow$ Keputusan Pembelian & $-0,0818$ & 0,8356 & Tolak $\mathrm{H}_{2}$ \\
\hline Green Output $\rightarrow$ Keputusan Pembelian & 0,2461 & $2,4149^{*}$ & Terima $\mathrm{H}_{3}$ \\
\hline Getok Tular $\rightarrow$ Keputusan Pembelian & 0,4664 & $6,7060^{*}$ & Terima $\mathrm{H}_{4}$ \\
\hline
\end{tabular}

Keterangan: * signifikan pada 5\%

Konstruk green input berpengaruh positif terhadap keputusan pembelian (nilai koefisien 0,2444 ). Artinya semakin baik input (komposisi produk dan bahan baku organik) yang digunakan produk, maka semakin tinggi pengaruhnya pada keputusan pembelian. Hasil penelitian ini sejalan dengan temuan Hakim (2010) bahwa green input berpengaruh secara nyata terhadap keputusan pembelian produk. Kesadaran responden akan dampak negatif yang ditimbulkan dari produk 98 berbahan kimia berbahaya membuat responden lebih berhati-hati dalam melakukan pembelian produk; baik itu kosmetik, toiletries, makanan dan minuman, maupun produk lainnya. Perusahaan yang memproduksi produk hijau dengan bahan alami dan bahan yang berasal dari pertanian organik dapat diidentifikasi oleh konsumen melalui keberadaan green label yang tercantum pada produk hijau. Temuan Sari pada tahun 2008 mendukung hasil penelitian ini, bahwa kandungan bahan baku produk menjadi pertimbangan utama konsumen dalam membeli makanan organik. Fan dan Zeng (2011) menambahkan bahwa masalah keamanan makanan utamanya ada pada bahan baku makanan. Hasil penelitian menunjukkan bahwa konsumen memperhatikan komposisi produk, bahan baku yang digunakan dapat diperbarui atau tersedia melimpah di alam, kandungan bahan pengawet produk, serta penggunaan bahan baku dari pertanian organik ketika memutuskan membeli produk dengan green label.

Hipotesis yang menyatakan green process berpengaruh terhadap keputusan pembelian tidak dapat diterima karena nilai $t$-statistics lebih kecil dari 1,960. Hasil ini mengindikasikan bahwa green process belum mampu mendorong konsumen dalam memutuskan membeli produk karena aspek ini tidak dilihat dan dirasakan langsung oleh konsumen. Efisiensi energi dan pengurangan emisi pada proses distribusi belum mampu memengaruhi konsumen untuk melakukan pembelian produk dengan green label. Mayoritas responden penelitian ini melakukan pembelian terhadap produk makanan dan minuman. Tedjakusuma et al (2003) mengemukakan bahwa faktor yang memengaruhi perilaku konsumen dalam pembelian produk, khususnya makanan dan minuman adalah faktor kualitas produk, distribusi, harga, dan promosi; karena hal-hal tersebutlah yang langsung dapat dilihat dan dirasakan. Sedangkan pengujian produk dengan konsep no animal testing tidak dapat dilihat dan dirasakan langsung.

Berdasarkan observasi, ISO 14000 yang merupakan kumpulan standar-standar pengelolaan lingkungan untuk menjamin diminimalisirnya dampak negatif proses perusahaan terhadap lingkungan, walaupun sudah dicantumkan tetapi belum dipahami masyarakat, sehingga konsumen susah mengidentifikasi apakah produk yang dihasilkan telah melalui proses yang ramah lingkungan. Oleh karena itu, green process belum mampu memengaruhi keputusan pembelian konsumen. 
Hasil penelitian menunjukkan bahwa dalam memutuskan pembelian produk dengan green label, konsumen masih belum mempertimbangkan penggunaan energi yang efisien dalam proses produksi, hasil limbah produksi, dan proses emisi yang terjadi selama produksi.

Temuan selanjutnya adalah konstruk green output berpengaruh positif terhadap keputusan pembelian dengan nilai koefisien 0,2461. Konsumen memperhatikan penggunaan kemasan biodegradable, eco label, dan sertifikat tertentu pada produk green label ketika akan membeli. Peningkatan kesadaran konsumen akan dampak negatif penggunaan kemasan yang sulit didaurulang atau sulit terurai mendorong konsumen mempertimbangkan untuk lebih memilih produk dengan kemasan biodegradable. Kemasan biodegradable tidak mengandung bahan-bahan yang berbahaya dan umumnya merupakan hasil daur ulang; seperti botol PET dari 100\% post consumer waste dan paper bag untuk menggantikan plastik.

Sertifikasi tertentu seperti eco-cert, ecoconscious product, FSC-Certified, dan certified sustainable palm oil juga menunjukkan bahwa produk dengan green label telah memenuhi standar internasional sehingga meningkatkan keputusan pembelian konsumen. Temuan ini didukung oleh penelitian Hakim (2010) dan Putripeni (2014) bahwa green output berpengaruh secara nyata dan signifikan terhadap keputusan pembelian produk berlabel hijau. Temuan Haryadi (2009) juga mendukung penelitian ini, bahwa pilihan pelanggan dipengaruhi oleh keberadaan label hijau.

Konstruk getok tular terbukti berpengaruh positif terhadap keputusan pembelian, dengan nilai koefisien 0,4664. Hal tersebut mengindikasikan getok tular berperan penting pada keputusan pembelian. Aspek-aspek getok tular yang memengaruhi keputusan pembelian produk dengan green label adalah product news, personal experience, dan advance giving sesuai dengan hasil temuan Assael (1998). Komunikasi getok tular sering dianggap iklan gratis karena seseorang sukarela menceritakan pengalamannya. Semakin sering mendengarkan hal positif produk, maka semakin tinggi rasa ingin mengkonsumsi dan memiliki produk tersebut (Destari \& Kasih, 2014). Peran dari grup acuan, yaitu keluarga, teman, tokoh masyarakat, dan para ahli dalam pengambilan keputusan dapat memengaruhi kepercayaan, sikap, dan perilaku seseorang pada waktu atau keadaan yang berbeda (Schiffman \& Kanuk, 2007). Prasetijo dan Ihalauw (2005) menambahkan bahwa perilaku konsumen dalam memutuskan pembelian didukung oleh semua faktor yang ada baik internal maupun eksternal. Faktor internal berasal dari kebutuhan mengkonsumsi suatu produk dan persepsinya terhadap produk tersebut. Sedangkan faktor eksternal berasal dari referensi keluarga, kelas sosial, budaya, dan kelompok acuan yang dimiliki konsumen.

\section{KESIMPULAN DAN SARAN}

Penelitian ini membuktikan bahwa dua aspek green product yaitu green input dan green output dapat memengaruhi keputusan pembelian konsumen, sedangkan karena tidak dapat dirasakan secara langsung oleh konsumen aspek lainnya yaitu green process tidak memengaruhi keputusan pembelian. Selain itu, diperlukan rekomendasi dari orang lain ketika seseorang memutuskan untuk membeli produk dengan green label melalui pemasaran dari mulut ke mulut (getok tular).

Implikasi dengan adanya pengaruh green input (komposisi produk dan bahan baku organik) terhadap keputusan pembelian, maka perusahaan sebaiknya meningkatkan kualitas dari bahan baku yang digunakan. Selain itu, karena green output berpengaruh positif terhadap keputusan pembelian maka perusahaan hendaknya memperkuat branding produk hijaunya melalui eco-label dan sertifikat tertentu yang dicantumkan pada kemasannya. Green process tidak memengaruhi keputusan pembelian konsumen karena tidak dapat dilihat dan dirasakan langsung. Oleh karena itu, perusahaan disarankan untuk melibatkan konsumen dalam program pelestarian lingkungan seperti reboisasi, pembersihan sungai, dan program CSR lainnya; sehingga konsumen merasakan secara langsung bentuk kepedulian perusahaan terhadap lingkungan. Untuk faktor getok tular, perusahaan harus mempertahankan kualitas yang dimiliki sehingga semakin banyak konsumen yang terdorong untuk merekomendasikan produk dan perusahaan kepada orang lain.

Penelitian selanjutnya terhadap keputusan pembelian produk hijau yang disarankan oleh peneliti adalah dengan menambahkan faktorfaktor psikologis yang terdiri atas perilaku, kepribadian, dan sikap konsumen untuk melihat sejauh mana faktor psikologis memengaruhi keputusan pembelian konsumen. Selain itu, dapat pula ditambahkan faktor moderasi yaitu pengetahuan konsumen yang diduga dapat 
memperkuat aspek pemahaman konsumen terhadap produk berlabel hijau yang pada gilirannya akan meningkatkan keputusan pembelian konsumen.

\section{REFERENSI}

Agustin, R.D., Kumadji, S., \& Yulianto, E. (2015). Pengaruh Green Marketing Terhadap Minat Beli serta Dampaknya pada Keputusan Pembelian. Jurnal Administrasi Bisnis (JAB), 22(2), 1-10

Aruman (2007) Sebuah Dunia Tanpa Promosi Penjualan. Majalah Mix Marketing, No. 10/ IV (22 Oktober-20 November), Hal. 20-21

Assael, H. (1998). Consumer Behavior and Marketing Action 6th Edition. New York: International Thomson Publishing.

Babin, B.J., Lee, Y.K., Kim, E.J., \& Griffin, M. (2005). Modeling Consumer Satisfaction and Word of Mouth: Restaurant Patronage in Korea. Journal of Services Marketing, 19(3), 133-139

Byrne M. (2003). Understanding Consumer Preferences Across Environmental Marketing Mix Variations. J Economic, 15(2), 65-72

Destari, N., \& Kasih, Y. (2014). Analisis Pengaruh Atribut Produk dan Word Of Mouth terhadap Keputusan Pembelian Tas Eiger di Kota Palembang, Jurnal Manajemen, Hal. 1-9

D'Souza, C., Taghian, M., Lamb, P., \& Peretiatkos, R. (2006). Green Products and Corporate Strategy: An Empirical Investigation", Society and Business Review, 1(2), 144-157

Fan, H., \& Zeng, L. (2011). Implementation of Green Marketing Strategy in China Thesis Unpublished. University of Gävle

Ghozali, I., (2008). Structural equation Modeling: Metode Alternatif dengan Partial Least Square (PLS), Semarang: Badan Penerbit Universitas Diponegoro

Hakim, A.R. (2010). Analisis Pengaruh Penerapan Konsep Green Marketing Terhadap Keputusan Pembelian Produk di Serambi Botani, Botani Square-Bogor. Bogor: Institut Pertanian Bogor

Handayani, N.T. (2012). Pengaruh Atribut Produk terhadap Loyalitas Pelanggan Green Product Sepeda Motor Honda Injection. Management Analysis Journal, 1(2), 1-2

Harjadi, D., \& Fatmasari, D. (2008). WOM 100
Communication sebagai Altenatif Kreatif dalam Komunikasi Pemasaran. Jurnal Sains Pemasaran Indonesia. 4(8): $72-78$

Harrison-Walker, L.J. (2001). The Measurement of Word of Mouth Communication and an Investigation of Service Quality and Customer Commitment as Potential Antecedents. Journal of Service Research, 4(1), 60-75.

Haryadi, R. (2009). Pengaruh Strategi Green Marketing Terhadap Pilihan Konsumen Melalui Pendekatan Marketing Mix Studi Kasus pada The Body Shop Jakarta. Tesis Tidak Dipublikasikan. Semarang: Universitas Diponegoro.

Hasan, A. (2010). Marketing dari Mulut ke Mulut, Yogyakarta: Medpress.

Ihalauw, J. J.O.I. (2013). Marketing Management-Improve Performance. Salatiga: Universitas Kristen Satya Wacana.

Jamrozy, U. (2007). Marketing Tourism: A Paradigm Shift toward Sustainability, International Journal of Culture, Tourism, and Hospitality Research, 1(2), 117-130

Kalafatis, S., Pollard, M., East R., \& Tsogas M.H. (1999). Green marketing and Ajzen's theory of planned behaviour: a cross-market examination Journal of Consumer Marketing. Sodality, 16(5), 441-460.

Kartajaya, H., \& Ridwansyah, A. (2012). Service with Character, Jakarta: PT Gramedia Pustaka Utama.

Kasali, R. (2005). Sembilan Fenomena Bisnis. Jakarta: Manajemen Student Society MSS FEUI.

Kotler, P., \& Armstrong, G. (2012). Dasar-dasar pemasaran. Jakarta: Erlangga.

Manongko, A.A. (2011). Green Marketing dan Pengaruhnya Terhadap Keputusan Pembelian Melalui Minat Membeli Produk Organik (Studi pada Pelanggan Produk Organik di Kota Manado), Malang: Universitas Brawijaya.

Miranti, S. (2012). Pengaruh Perbedaan Jenis Kelamin terhadap Perilaku Pembelian Produk Ramah Lingkungan di Jakarta. Tesis Tidak Dipublikasikan. Universitas Indonesia.

Moisander, J., \& Pesonen, S. (2002). Narratives of Sustainable Ways of living: Constructing The Self and The Other As A Green Consumer. Journal 
Management Decision, 40(4), 329-342

Peter, J.P., \& Olson, J.C. (2006). Consumer Behavior: Perilaku konsumen dan Strategi Pemasaran. Jakarta: Erlangga.

Putripeni, M.P. (2014). Pengaruh Green Marketing terhadap Citra Merek dan Keputusan Pembelian. JAB. 10(1)

Schiffman, L.G., \& Kanuk, L.L. (2007). Consumer Behavior. (9th ed.). New Jersey: Pearson Prentice Hall.

Setiadi, N.J. (2003). Perilaku Konsumen. Jakarta: Penerbit Prenada Media.

Setiyaningrum, A., Udaya, J., \& Efendi. (2015). Prinsip-prinsip Pemasaran. Yogyakarta: Penerbit ANDI.

Solomon, M.R. (2011). Consumer Behavior: Buying, Having, and Being, USA: Prentice Hall.

Sumardy, Silviana M., \& Melone, M. (2011). The Power of Word of Mouth Marketing, Jakarta: PT Gramedia Pustaka Utama.

Swastha, B., \& Irawan (2008). Manejemen Pemasaran Modern, Yogyakarta: Liberty.

Syahbandi. (2012). Implementasi Green Marketing Melalui Pendekatan Marketing MIX, Demografi dan Pengetahuan terhadap Pilihan Konsumen (Studi The Body Shop Pontianak)", Jurnal Ekonomi, Bisnis dan Kewirausahaan, 3(1), 68-85.

Utomo, T.H.A. (2015). Produk Hijau Indonesia. http://www.indonesiagreenproduct.com/ produk-hijau-indonesia/. Diakses tanggal 17 Desember 2016.

Wirtz, J., \& Chew, P. (2002). The Effects of Incentives, Deal Proneness, Satisfaction and Tie Strength on Word of Mouth Behaviour. International Journal of Service Industry Management, 3(2), 141162. 
Jurnal Manajemen Maranatha ø Vol. 17 Nomor 2, Mei (2018) 